\title{
The Dynamics of the Developing Calcarenite Member of Pamutuan Formation in Cintaratu Area, Pangandaran, West Java
}

\author{
Vijaya Isnaniawardhani*, Billy G. Adhiperdana*, Adjat Sudradjat ${ }^{*}$ Nana Sulaksana* \\ *Faculty of Geological Engineering, Universitas Padjadjaran, Jalan Raya Bandung-Sumedang Km 21, Jatinangor 45363 \\ E-mail: vijaya.isnania@unpad.ac.id
}

\begin{abstract}
The investigated area is located in Cintaratu, Parigi District, Pangandaran Regency in the Southeastern part of Southern Mountain of West Java. The rock unit in the investigated area is described as the Calcarenite Member of the Pamutuan Formation. The present study applying detailed lithologic and paleontologic description reveals five lithologic units. Combining the field method with microscopic analysis leads to the verification of the age and environments of this carbonate rocks. The study concludes the development of reef complex in Early Mid Miocene, followed by the high energy of the dynamic environment producing the fragments of the lime clasts embedded in the packstone, indicates the deposition in the fore slope. The regression took place and moved the deposition environment to the low-energy condition at the back of the reef, producing bioclastic packstone containing larger foram. Rising seawater level amplified the dynamics of the seawater in mid-Middle Miocene. The formation of planktic packstone marked an initial transgression phase that was well-represented as regional transgressive in Southeast Asia. This phase continued until interbedded calcareous mudstone and sandstone were produced. Finally, in Late Mid Miocene the sea level regressive accumulated coarse materials of calcarenite grain size containing fragments of larger foram within shallower deposition environment. The NNW-SSE elongated distribution of five units of Calcerinite Member pointed out the configuration of Middle Miocene coastal line. In Early Middle Miocene, various carbonate rocks formation was primarily controlled by tectonic activities. Afterward, the rock deposition affected by the regional sea level rise and drop during Mid to Late Middle Miocene. The detailed description of the Calcarenite Member, therefore, contributed to the understanding of the paleogeography of Mid Miocene age and the dynamics of the environmental deposition.
\end{abstract}

Keywords - Calcarenite Member; Pamutuan Formation; dynamic environment; reef; paleo coastal line

\section{INTRODUCTION}

The Indonesian archipelago is a part of the broader tectonic plate margin of the Southeast Asian continent, Sunda land. In terms of plate tectonic framework, the Indonesian archipelago is represented by the presence of sophisticated characteristics of the arcs in the convergent margin with active tectonism and magmatism recording the complex interactions of the Asian, Pacific, and IndianAustralian lithosphere major plates and many other microplates. The most typical tectonic element in this Southeast Asian margin of Indonesian islands is the present of Sunda Subduction system or Sumatra-Java arc-trench system. This subduction system identifies the plate boundaries situated along Sumatra, Java, Bali to the lesser Sunda islands to the east [1].

In this setting of convergent plate boundaries, the Indian ocean plate has been continuously subducted beneath the overriding plate of Sunda land continent margin. The Sunda land margin itself is the product of several accreted
Gondwana margins which has been drifted northward along with the Australian plate since early Mesozoic. These many accreted continental plates are typified by several sutures of the Paleo-Tethys oceans, which have been completed into the present configuration in the late Mesozoic to early Cenozoic. Significant portions of Cenozoic sedimentary basins have been developed in this arc-trench setting at the rear-arc position of the present magmatic arc [2].

The basement of Java Islands consisted of metamorphic rocks of Jurassic age. In Paleocene time the subduction took place along the line extended from Ciletuh in West Java to Lok Ulo and Bayat both in Central Java and continued to Meratus in Kalimantan. In Oligocene, the subduction rolled down to the South located a few kilometers South of Java on the Indian Ocean. This tectonic process produced Tertiary magmatic arc in the southern part of West Java where volcanic eruptions and intermediate and acidic intrusions took place. Evidence of the earliest magmatic event is represented by Jampang Formation (Oligocene-Early Miocene) which is limitedly distributed along the south coast 
of Java from Pacitan in East Java as far as PelabuhanratuBayah area in the west through Bayat, Parangtritis, Kulon Progo, Lok Ulo, Pangandaran, and Cikatomas. In Pangandaran-Cikatomas area, many lava flows and laharic breccias of Jampang Formation (17.6 - 17.9 MY BP) are exposed [3]. Before the formation of the volcanic island arc, a relatively short span of times occurred in Paleocene and Eocene periods producing turbidite and volcanoclastic sediments (Ciletuh and Bayah Formations) showing the environment of the deep and steep basin which later developed to be very shallow.

The evidence shows that while in the west the tectonic activities already uplifted the Southern Mountain, in the investigated area the volcanic arc remains under the sea. The process might be accompanied by the formation of Cimandiri basement which involved the faultings in the West and the development of Citanduy Fault in the East.

In the eastern part of Southern Mountains, andesitic to laharic lava flows and volcanic breccia of Jampang Formation are conformably overlain by fine-grained siliciclastics and volcaniclastics of Pamutuan Formation. The mid-succession namely the carbonate strata are exposed (known as Calcarenite Member of Pamutuan Formation/Tmpl); intercalated with tuff and marl (Marly Tuff Member of Pamutuan Formation/Tmpt). The Tertiary rocks are covered by alluvium [3], [4] (Fig. 1).

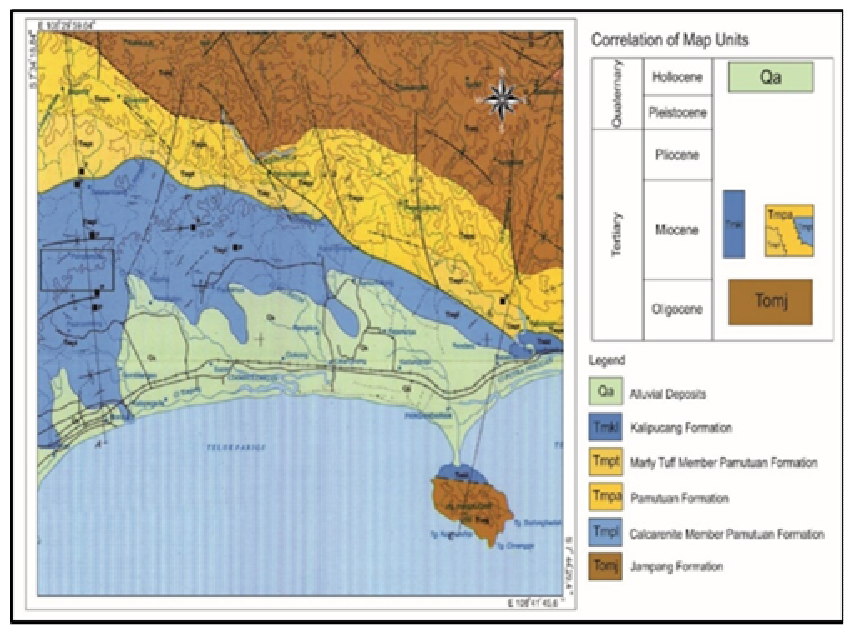

Fig. 1 Regional geologic map of Cintaratu area and its surroundings [3]-[4]

Further, the tectonic activities continued resulting in the reactivation of the deep-seated faults and the skin folding and faulting in the Tertiary sediments. The subduction moved northward to the present Sunda Through, which is located a few kilometers south of Java. The new subduction might have taken place in the Upper Tertiary and Early Quaternary and uplifted the whole Java Island accompanied by volcanic activities. The tectonics of the investigated area might have been influenced by the regional fault of Citanduy and the continuing compression of the regional tectonics of Java Island.

The uplifting produced folding and thrusting on both sides of Java Island. In the South flank, the fold inclines to the South, while in the North it faces to the North direction. Both the folding and thrusting which involved the younger sediments are strongly associated with the reactivation of the regional basement faulting.

Recent and ancient volcanic arcs have commonly provided sites for extensive shallow water carbonate production. Volcanic clastic sediments, particularly finegrained particles, are believed to have a strong detrimental effect on carbonate production. At the front of the Southern Mountains of Java, Oligo-Miocene carbonate has developed within the intra-arc setting. The window of volcanic quiescence which occurred contemporaneously with the eustatic level rising during Middle Miocene (18-12 MY BP) resulted in significant carbonate complex development [5].

Carbonaceous rocks are mostly formed in carbonate platform complex in tidal flat, lagoon, shoal and basin; some are also found in terrestrial environments. The forming process of this rock is more complicated than siliciclastic rock because basically the process of the formation is not solely sedimentation. A succession of strata and facies geometry develop in response to sediment flux and the available space for sediment accumulation. In carbonate system, these three parameters are highly interdependent: (1) Sediment input highly depends on biological activity and consequently on condition of the environment (temperature, nutrient, salinity, etc.). (2) Sediment dispersal depends on production loci and on the interaction between the amount and type of sediment being produced as well as the water energy, also biological activity and post-genetic process. (3) Accommodation with respect to sediment input, type, and area of the carbonate factory depends on sea-floor morphology and sea-level changes [6].

Studies on carbonaceous rock require integrated works between rock outcrops or drilling data and laboratory analysis in term of uncovering sedimentological and paleontological features. Regarding field and laboratory analysis data, facies and depositional environment have been recognized. A description of the outcrop intends to identify major features, such as bedding plane, gradation, sedimentary structure, fossils and geometry [7], [8]. Microscopic observation on texture, composition (percentage of fragmented and/or non-fragmented shells, the percentage of micrite and terrigenous material, grain size composition), allochem type, diagenetic and microfossils content provide guidance on finding carbonate facies, index energy, sequence stratigraphy and depositional environment [9]-[11]. Field investigation and microscopic observation have been applied to facies and depositional interpretation of ancient carbonate several basins in Asia [8]-[10], [12], [13], including Indonesia [14].

Foraminifera, algae, corals, bivalve mollusc, gastropods, brachiopods, and ostracods give a direction on concluding depositional environment of carbonate rocks [7], [15], [16]. Larger benthic foram led to an understanding of age, facies relationship, paleoenvironment, and succession of this rocks [16]-[18]. Analyses of the larger benthic foram in South Central Java [19], southeast Kalimantan [20] and several basins in Indonesia [21] have allowed accurate dating of the carbonate sections studied using the Adam's East Indian Letter Classification.

The physical and biological characteristics of the carbonaceous rock from Cintaratu area, Parigi District, Pangandaran Regency, West Java have been studied to 
understand the dynamics of its formation in the sedimentary basin. Geographically the investigated area is located at the longitudes $108^{\circ} 29^{\prime} 39.29^{\prime \prime}$ West and $108^{\circ} 31^{\prime} 34.27^{\prime \prime}$ West and latitudes $7^{\circ} 38^{\prime} 21.68^{\prime \prime}$ and $7^{\circ} 39^{\prime} 36.22^{\prime \prime}$ South, covering the area of approximately $5 \mathrm{~km}^{2}$. The location is about $18 \mathrm{~km}$ from the tourist destination of Pangandaran in the direction of Cijulang (to the West) and can be reached on $15 \mathrm{~km}$ of main road and $3 \mathrm{~km}$ smaller access after turning left to the North in Citumang junction (Fig. 2). The paleoenvironment becomes the objective of this investigation aiming to contribute in clarifying the dynamic condition during the formation of the rocks based on the stratigraphic position. The detailed mapping supported by lithologic and paleontological characteristics description put forward in this study in the Southeastern part of West Java Basin will provide a better understanding on the evolution of the carbonate succession which will contribute to the wider economic value of the carbonate in this particular basin.

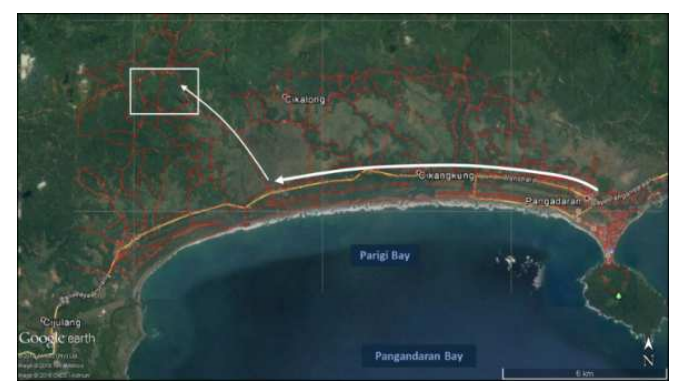

Fig. 2 Location and access to the research area (Base map: Google earth)

\section{MATERIAL AND METHODS}

The literature study was first done, and general mapping was then carried out. Measured sections were carried out in selected locations, where samples for laboratory analysis were collected. The correlation between measured columns was prepared to help in the interpretation of the lateral and vertical distribution of the rocks based on the physical characteristics. Remote sensing processing on Landsat TM Overdrape (DEMASTER GDEM Worldwide Elevation Data) over the investigated area was prepared and proved to enhance the delineation of lateral distribution of the rock [21].

The determination and classification of rock units in the field were done to help the selection of samples for microscopic observation. Since the area composes mainly of carbonate and its associations, field investigation describes the lithological characteristic of the rock sequence including the graduation, sedimentary depositional structures, and fossils. Based on laboratory analysis microscopic thin sections are used to observe the features of microscopic facies (namely grain size, grain shape, sorting, the relationship between grains - matrix - cement, the composition of skeletal and material of rocks), diagenetic characteristic and microfossils [8]-[16].

Identification of larger foram marker species and their living range were conducted with reference to previous studies [17], [19], [20], [22]. Based on the stratigraphic position of strata accompanied by the appearance of fossils marker, the rock succession can be identified. Adam's East Indian Letter Classification with its revision is used to determine age. The age of siliciclastic strata was determined based on the reference of many horizon foraminiferal biostratigraphy of Miocene planktonic foraminifera that was widely applied in several basins in Asian and specifically in Indonesia [22]. The appearance and abundance of larger benthic foramas well as smaller forms and other associated fossils [7], [15]-[17] contribute to the verification of petrographic analysis concerning the interpretation of the depositional environment.

\section{RESULTS AND DISCUSSION}

\section{A. Geomorphology}

Physiographically the investigation area is a part of the Eastern portion of the East-West trending Southern Mountain with relatively low altitude. Geomorphologically, this area forms hills showed by the NNW-SSE, NW-SE, NESW, and NNE-SSW directed ridge patterns where southeast parts have higher elevations in the southeast, in another side lower parts of the northwest. The investigated area is composed of a relatively undulated terrain with the slope of 5 to $30 \%$ dipping South and the top somewhat flat at the elevation of 152 meters above sea level. The lowest terrain locates at the elevation of 38 meters above sea level (Fig. 3).

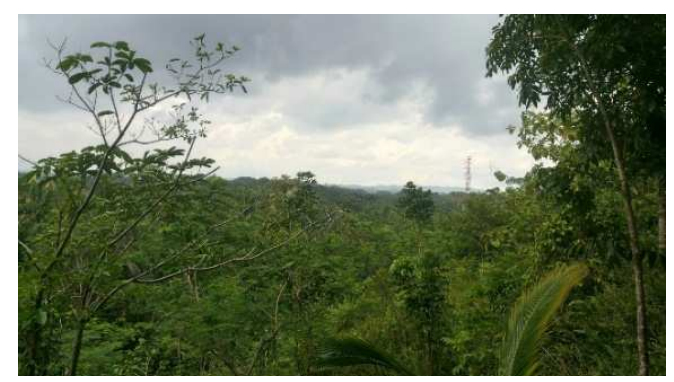

Fig. 3 The general morphology of the investigated area looking East

\section{B. Lithological and Paleontological Characteristics of Calcarenite Member of Pamutuan Formation}

Calcarenite Member (Tmpl) conformably overlies Pamutuan Formation (Tmpa) and is intercalated with Tuff Member (Tmpt) [3], [4] (Fig. 1). The contact of these rocks units is exposed northward from the investigated area.

1) Overlain Rock: The lower part of Pamutuan Formation consists of calcareous sandstone intercalated with calcareous claystone. The weathered sandstones are yellowish brown in color and light grey when they are fresh. The grain size is very fine to medium sand sizes, containing volcanic material fragments and locally limestone pieces. The rock is well stratified with the thickness between 3 to $80 \mathrm{~cm}$. The sedimentary microstructure consists of planar parallel, cross, ripple and wavy laminations. In places, the calcareous mudstone intercalations are observed with the thickness between $1 \mathrm{~cm}$ to $10 \mathrm{~cm}$.

Hand specimens, taken from basal part of Pamutuan Formation contain planktic foram such as Globigerinoides ruber, Globigerinoides subquadratus, Orbulin abilobata, Orbulina suturalis, Orbulina universa, and Sphaerodinellopsisdisjuncta besides the zonal markerGloborotalia fohsi peripheroronda. The appearance of the genus Orbulina is important as a marker for the approximate 
base of the Globorotalia fohsi peripheroronda zone. In Indonesian basins, datum on the first appearance of Orbulina suturalis is used to define the base of Middle Miocene or Zone N.9 of the Blow's planktic foram zonal scheme [22], [23]. This datum is considered reliable for global correlation and is reported to have ages of 15.1 MY BP [24].

Furthermore, the Globorotalia fohsi peripheroronda zone is marked by the first appearance of the genus Sphaerodinellopsis represented by small specimens of Sphaerodinellopsis disjuncta. Another foram planktic, used as identifier for Miosen, can be found within microfossils among others are Globigerinoides obliquus, Globorotalia continuosa, Globigerinoides trilobus group, Globorotalia obesa and Globorotalia mayeri.

Upward, closer to the contact with Calcarenite Member, change of foram collection are recorded by the appearance of Globorotalia fohsi from its lineage ancestry, Globorotalia fohsi peripheroronda. It is equivalent to N.10. This sample also has similar assemblages by the same species as at the bottom.

Benthic form assemblages dominated by typical inner neritic genera among others: Ammonia, Elphidium, and Operculina associated with Bolivina, Dentalina, Eponides, Fursekoina, Gyroidina, Lenticulina, Neoponides, Nodosaria, Peneroplis and Siphotextularia, identify that the calcareous sandstone of Pamutuan Formation was deposited in the shallow marine (20 meters to 50 meters).

2) Calcarenite Member of Pamuluan Formation: The succession of Calcarenite Member is exposed in the investigated area divided into five facies, namely:

- Intraclast-larger foram bioclastic packstone

- Larger foram bioclastic packstone

- Planktic foram bioclastic packstone

- Interbedded calcareous mudstone-calcareous sandstone

- Larger foram bioclastic grainstone.

The lateral spreading of this unit was illustrated by satellite imagery interpretation respect to the field mapping effort (Fig. 4).

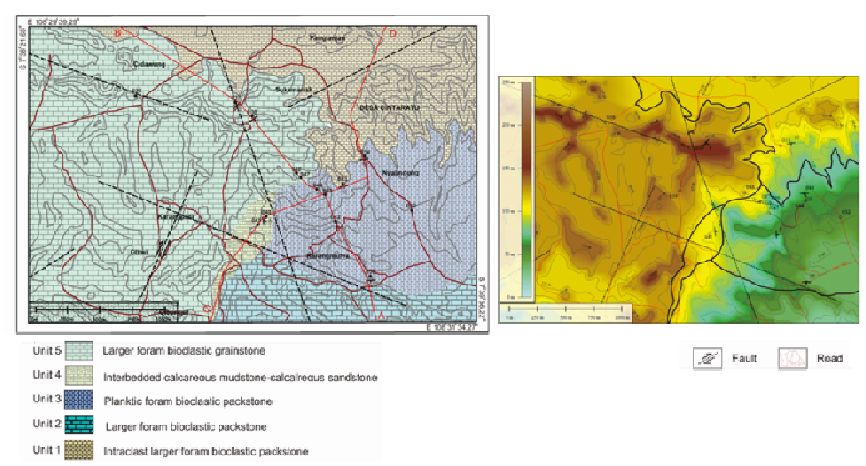

Fig. 4 The geologic map and Landsat TM Overdrape DEMASTER GDEM Worldwide Elevation Data) showing five units of the rocks exposures in the investigated area

Vertical distribution of rocks was correlated based on geologic cross section compiled by measured section (Fig. 5).

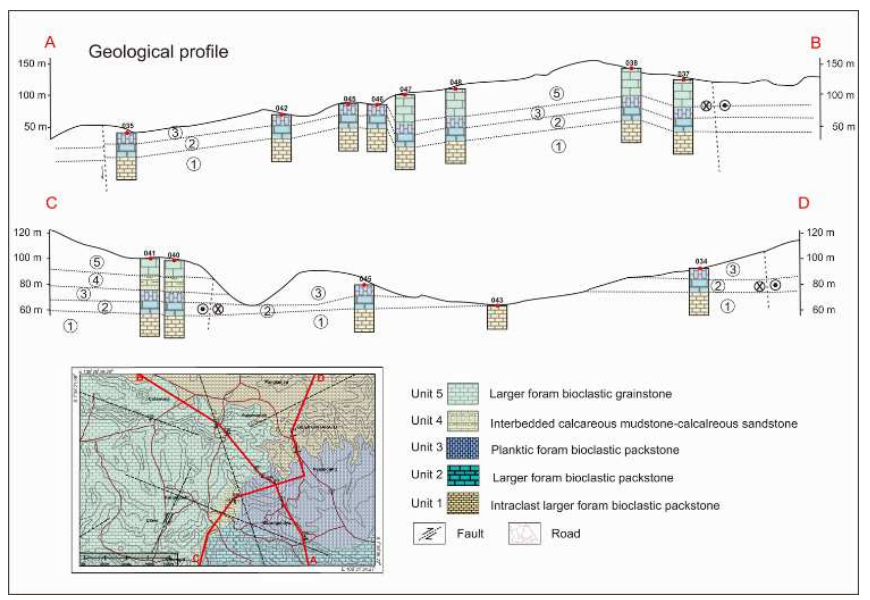

Fig. 5 The geologic cross section of the investigated area with the correlation of the measured section

\subsection{Intraclast-Larger Foram Bioclastic Packstone (Unit 1) \\ Lithological Characteristics:}

This unit belongs to the oldest rock unit in the investigated area located in the E-NE portion. The rocks cover about $21 \%$ of the area and can be classified as clastic limestone. The physical characteristics of the fresh granular limestone are whitish brown; the weathered rocks are brownish yellow, dominated by medium to coarse sand grain sizes $(1 / 2 \mathrm{~mm}$ to $1 \mathrm{~mm})$, containing lithified and intermediately lithified lime clasts (intraclast), sedimentary rocks, and skeletal fossils fragments, (Fig.b6). Heterogeneous texture and composition of fragments are embedded in the matrix. Cross-bedding and wavy laminations were recorded in some outcrops.

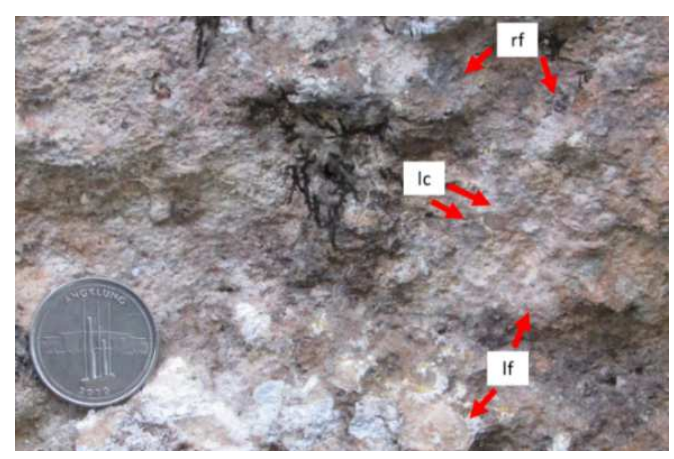

Fig. 6 The surface expression of rock fragments (rf), lime clast (lc) and larger foram shell (lf) in intraclast larger foram bioclastic packstone unit

The microscopic observation of the rock specimens (Fig. 7) reveals the intraclast-larger foram bioclastic limestone. The rock composed of predominant angular shape, poorly sorted of lime clasts and rock fragments (maximal 10\%), fossil fragments (50-55\%), K-feldspar mineral (1-3\%), micro quartz or poly-crystalline $(1 \%)$. Those fragments are embedded in the micrite dominated matrix (10-20\%) and cement $(2-6 \%)$.

The crystallized calcite minerals are frequently identified in the outer foram clasts with the overgrowth texture. Many fossils appear broken or weak (abraded). Various porosities are also observed such as intraparticle, interparticle, moldic and vuggy porosity with the amount exceeds $2 \%$.The 
presence of intraclasts of coral limestone indicates that the source rocks are closely located.

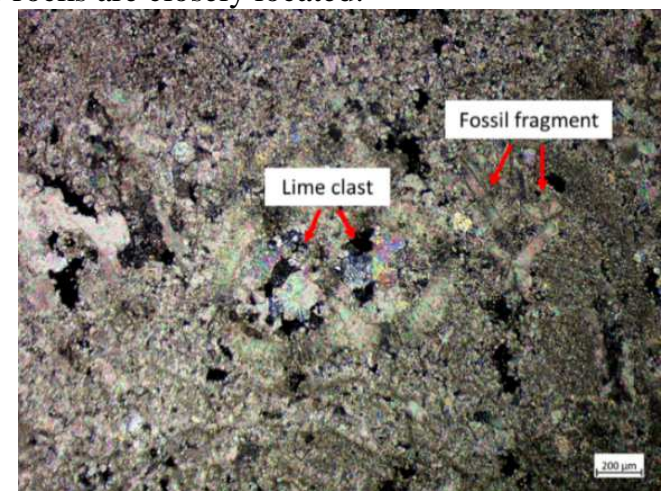

Fig. 7 The thin section shows fossil fragments, minerals and limestone clasts of Unit 1

\section{Paleontological characteristics:}

The appearance of larger benthic foram species marker Heterostegina (vlerkina) borneensis in association with Katacycloclypeus annulatus and Lepidocyclina (Nephrolepidina) (Fig. 8) indicates the Tf1 stage of Adam's letter classification [20]. This zone is identified within the Early Middle Miocene period. This stage is determined corresponding to 18.7 MYBP [24].

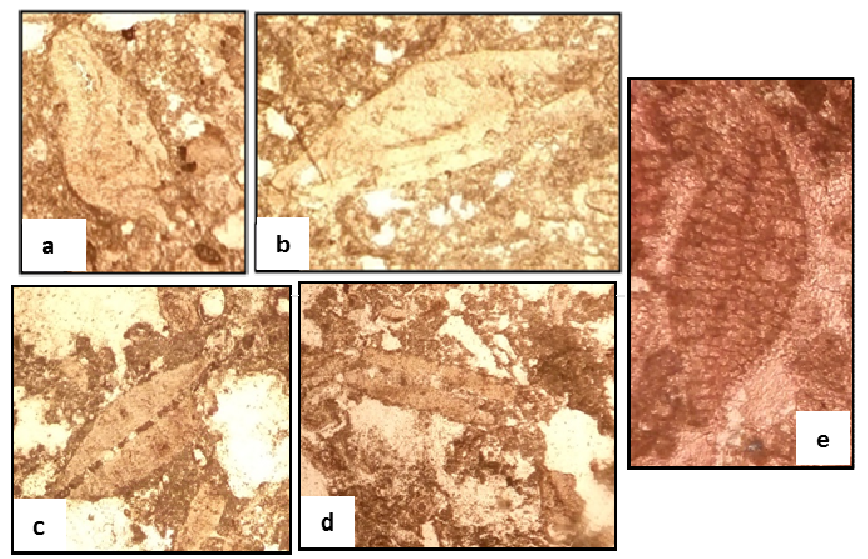

Fig. 8 Photographs exhibit Heterostegina (vlerkina) borneensis(a, b), Katacycloclypeus annulatus (c,d)and Lepidocyclina (Nephrolepidina)(e) in intraclast larger foram bioclastic packstone asindex fossils of Early Middle Miocene

The abundant larger foram (such as Amphistegina, Heterostegina, Cycloclypeus, Planorbilinela, and Alanlordia) associated with coral, red algae and planktic foram with a limited number of small rotaloid and miliolid reflects depositional process occurring in the fore reef with high sunlight intensity. Many skeletal limestones fragments containing stromatolite and foram (Fig. 9) illustrate the rock unit formation taking place at a slope in front of the reef's body. The similar fossil index (Heterostegina (vlerkina) borneensis and Katacycloclypeus annulatus) observed in both limestone clasts and matrix indicatea syn-genetic process.

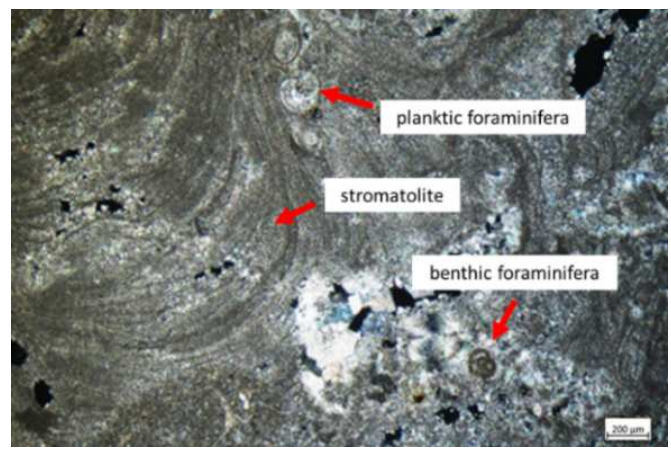

Fig. 9 Stromatolite, planktic and small benthic foram in a non-clastic lime clast fragment

\subsection{Larger Foram Bioclastic Packstone (Unit 2)}

Lithological characteristics:

Overlaying the older rocks, this unit consists of wellcemented clastic limestone, grain supported, poorly stratified, with the average thickness of $15 \mathrm{~cm}$ (Fig. 10). It covers about $12 \%$ of the investigated area in the S-SE portion.

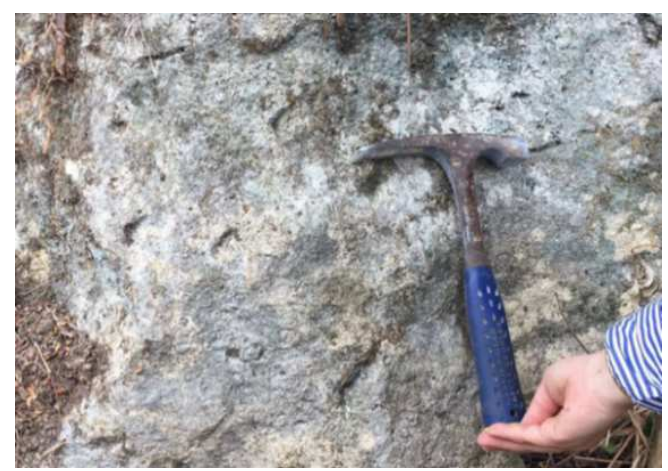

Fig. 10 The surface expression of bioclastic packstone outcrop

Microscopically the bioclastic limestone composes of fossil fragments $(55 \%-57 \%)$, K-feldspar (1\% - 2\%), and pyroxene $(1 \%)$ embedded in the micrite and clay matrix $(20 \%$ - 28\%) with sparit cements $(1 \%$ - 3\%). In places carbonate fragments were found $(<5 \%)$. The fossil shells are mostly whole, undamaged, and are not abraded (Fig. 11). Various porosities are observed such as intraparticle, interparticle and vuggy porosity, in places moldic, with the amount exceeding $25 \%$.

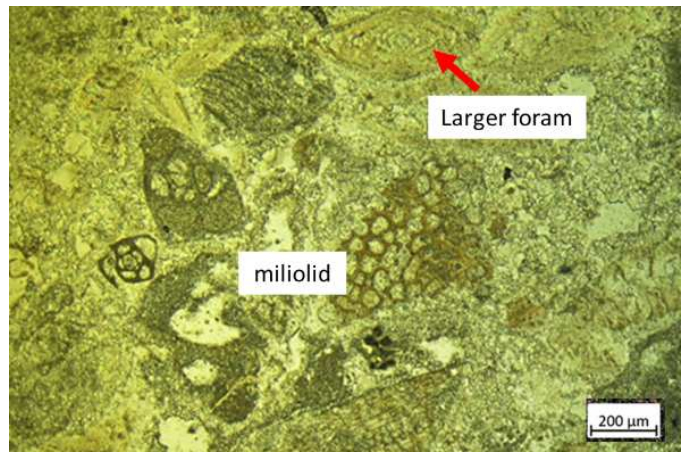

Fig. 11 Various fossils fragments embedded in matrix micrite

\section{Paleontological Characteristics:}

The presence of larger foram as index fossil such as Austrotrillina howchini and Katacycloclypeus annulatus indicates the bioclastic packstone of Middle Miocene age 
(Fig. 12). The last appearance of Austrotrillina howchini marks the top of Tf2 [20]. This zone is well recognized in Southeast Asia as widespread carbonate development phase.
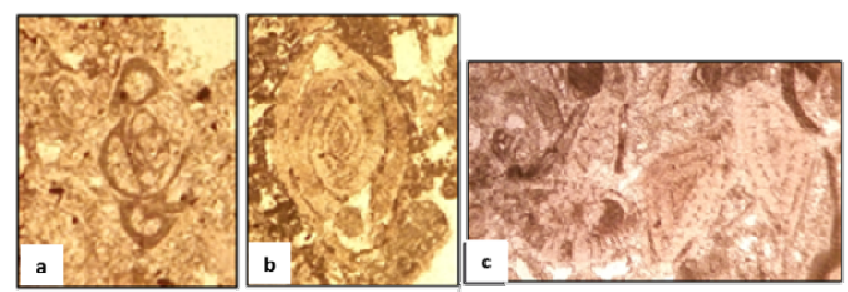

Fig. 12 Austrotrillina howchini (a) as the index fossil indicating the age of Middle Miocene. Few Amphistegina spp. (b) and Calcarina spp. (c) are found in bioclastic packstone

The high diversity of larger foram with abundant small miliolid and rotaloid, few green algae (Halimeda), coral, bryozoan and mollusc indicate back reef environment. The fossil marker - Austrotilina is generally found in this environment. The larger foram domination, as well as the presence of lime mud, indicate a low-energy condition.

\subsection{Planktic Foram Bioclastic Packstone (Unit 3)}

\section{Lithological Characteristics:}

The planktic foram bioclastic packstone unit in the investigated area covers the S-SE portion about $6 \%$ of the total area. This unit consists of well-cemented clastic limestone, yellow to brownish yellow colour, in the weathered condition the colors are brownish yellow, lithologically dominated by grains with the domination of fine sand grain size $(1 / 16 \mathrm{~mm}$ to $1 \mathrm{~mm})$. In some places, parallel and cross beddings are found (Fig. 13).

The thin sections analysis of rock samples reveals rounded shaped fragments of predominated planktic foram $(60 \%-$ $65 \%$ ), more varied mineral fragments consisting of $\mathrm{K}$ feldspar, glauconitic, amphibole, plagioclase) (5\% - 10\%) which are embedded in the lime mud and micrite matrix $(15 \%)$ and carbonate cement $(5 \%)$.

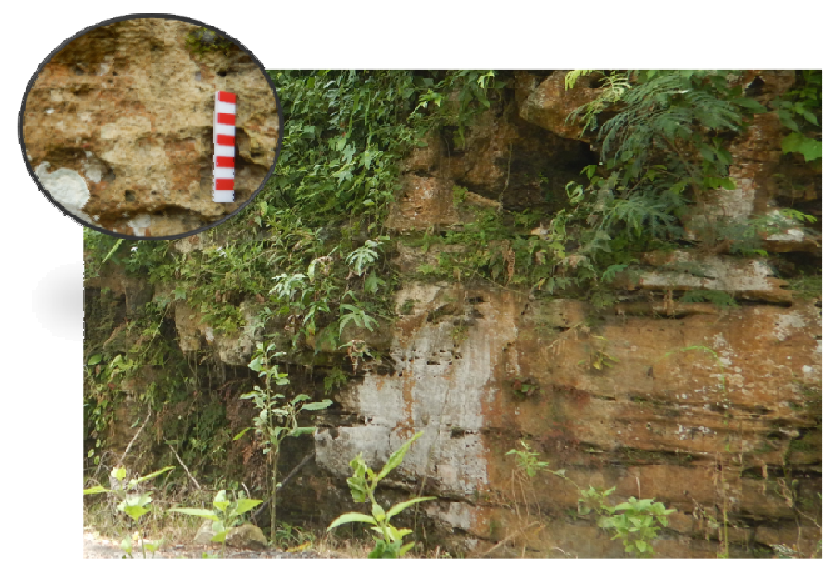

Fig. 13 The photograph shows the stratified limestone of unit 3 and its surface expression (inzet)

\section{Paleontological Characteristics:}

Planktic foram - Globigerinoides ruber, Globigerinoides subquadratus, Globorotalia fohsi group, Sphaeroidinellopsis subdehiscens, Hastigerina siphonifera and Globorotalia menardii are contained in the collected samples (Fig. 14).
The appearance of Globigerinoides ruber, extinction of Globorotalia fohsi group without the presence of younger zonal index (Globigerina nepenthes) marks Globigerinoides ruber zone or N.13. In Indonesian basins, the first appearance of Sphaeroidinellopsis subdehiscens is used to mark the base of this zone [22]. This datum is recognized at 11's MYBP[24].

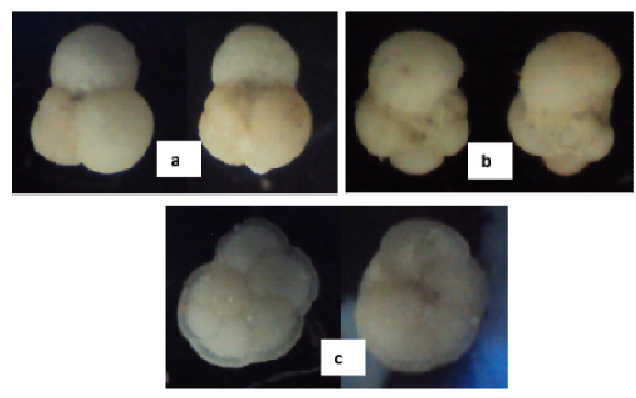

Fig. 14 Globigerinoides ruber (a), Hastigerina siphonifera (b) and Globorotalia menardii (c) asindex fossils of N.13 of Blow's zone

The abundance of planktic foram increases significantly in this unit compared to the position in clastic limestone formed earlier (Fig. 15).

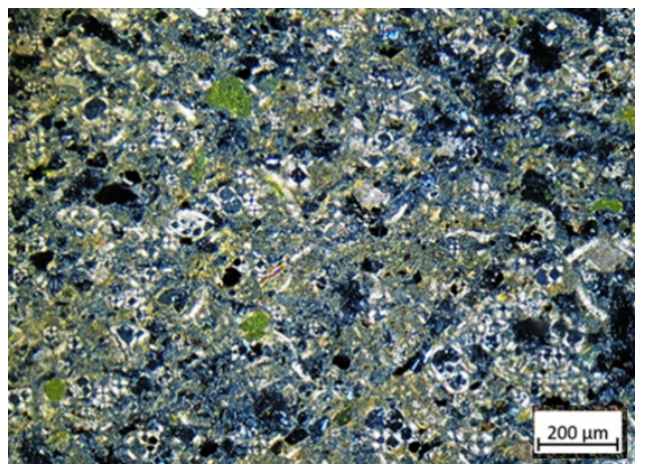

Fig. 15 Planktic form is predominant in bioclastic limestone unit 3

\subsection{Interbedded Calcareous Mudstone-Calcareous Sandstone (Unit 4)}

Lithological characteristics:

The rock in the investigated area covers $6 \%$ of the area in the SW portion. The rock is classified as clastic sediment. It composes of the alteration between grey calcareous mudstone and calcareous sandstone. It is poorly cemented and moderately weathered at the surface (Fig. 16).

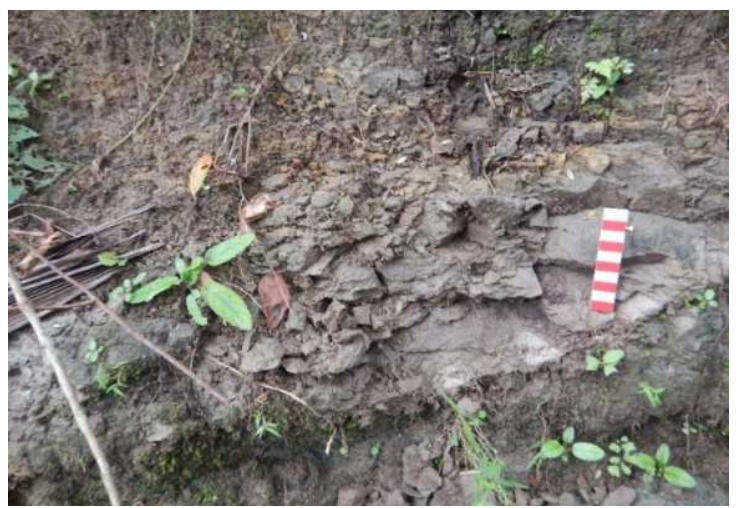

Fig. 16 The photograph shows the appearance of interbedded calcareous mudstone and calcareous sandstone (Unit 4) 


\section{Paleontological Characteristics:}

Four samples taken in clay and sandstone layers in this unit show the fossil foram content similar to the underlying unit. Thus it can be concluded that both are the same age. Well-developed foram assemblages of the high ratio planktic form $(87 \%)$, and abundant benthic typifying the middle neritic (among other Lenticulina, Bulimina, and Hypermmina) in addition to the assemblages in lower unit indicate deeper setting (Fig. 17).

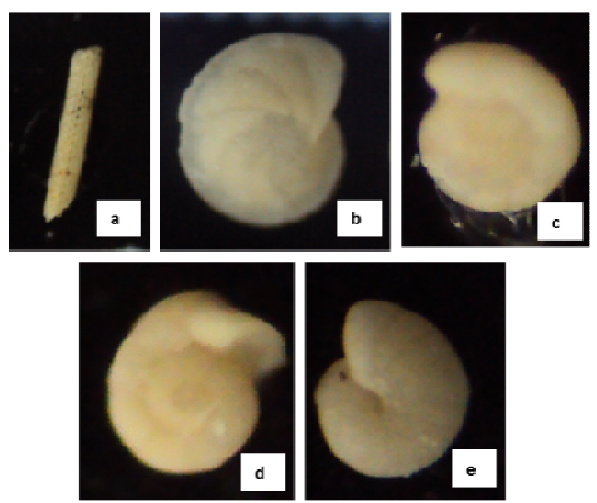

Fig. 17 Genera Hypermmina (a), Lenticulina (b), Ammonia (c), Cibicides (d) and Anomalinoides (e) are found in a middle neritic calcareous mudstone sample

\subsection{Larger Foram Bioclastic Grainstone (Unit 5)}

\section{Lithological Characteristics:}

The youngest rock covers $55 \%$ of the area in the WNW portion. It is classified into clastic limestone, characterized by predominated coarse sand grain size fragments $(1 \mathrm{~mm}-2$ $\mathrm{mm})$. It is poorly cemented and weathered at the surface with intensive cavities (Fig. 18). In the thin section, the limestone shows the composition of fossil fragments (55\% $65 \%$ ) consisting mainly of larger benthic foram and a small number of algae. It also consists of K-feldspar (2\%-5\%), grained supported carbonate minerals $(8 \%$ - 15\%) with embedded micrite $(<5 \%)$ and carbonate-cemented $(3-5 \%)$. Fracture and vuggy porosities are largely found.

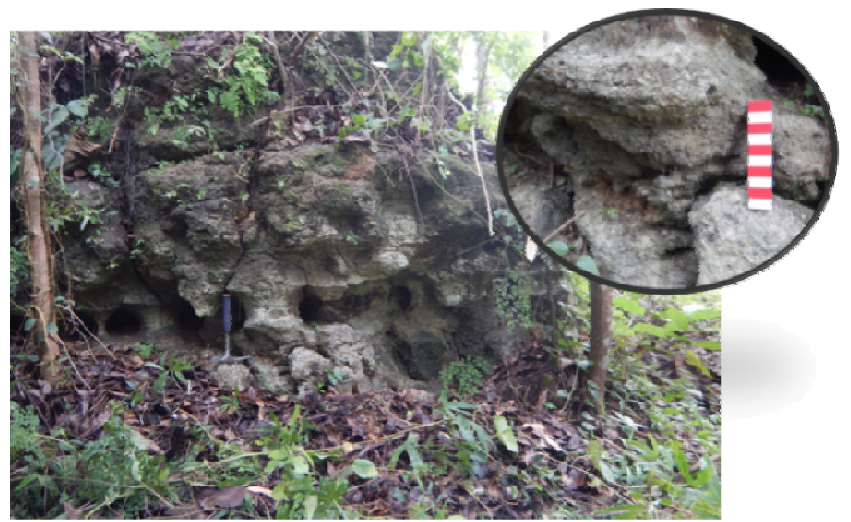

Fig. 18 The photograph shows the surface appearance of limestone rock unit 5

\section{Paleontological Characteristics:}

The appearance of larger foram species index, Lepidocyclina (Neprolepidina) rutteni quadrata indicates the formation of limestone sandy-skeletal grainstone in Tf2 or latest Middle Miocene [22]. Based on the characteristics and the biota assemblages it is interpreted that the limestone was deposited in the back reef. The regressive of sea-level is continuing during the deposition of the limestone of this unit.

\section{3) Covered Rocks}

The five facies succession of Calcarenite Member is conformably overlain by bright grey to bluish well-stratified calcareous mudstone, with the average thickness of about 8 to $15 \mathrm{~cm}$ containing benthic and planktic foram and algae, intercalated with fine-grained sandstone. The foram is welldeveloped, composing of planktic taxa (Globigerina nepenthes, associated with Globorotalia mayeri, Globorotalia obesa, Globigerinoides trilobus group, Globoquadrina altispira group, Orbulinauniversa, Globigerinoides obliquus, and Globigerina praebulloides) including benthic form (genera Globocassidulina, Euvigerina, Floresina, and Siphotextularia). The extinction of Globigerinoides subquadratus found in the previous unit becomes a hallmark of N.14 or Middle Miocene. Some workers, for instance, use the first appearance of Globigerina nepenthes [22], or last appearance of Globigerinoides ruber to mark the base of this age zone. Particulary in the investigated area, this species is very rare. The assemblages are composed of abundant and diverse taxa with a predominance of typically neritic zone indicating shallow marine environment (20 - $100 \mathrm{~m}$ depth).

\section{Structural Geology}

In general, the Calcarenite Member rock layers show a sloping angle of less than $10^{\circ}$ and even some are found horizontally, flat-bedded, with a strike between $\mathrm{N} 15^{\circ} \mathrm{E}$ to $\mathrm{N} 17^{\circ}$ E. These rocks are controlled by NNW-SSE, NW-SE, NE-SW and NNE-SSW direction patterns, shown by the straightness of ridges and hills (Fig. 5). The presence of fractures, veins, joints, and movement of the rock layers observed in the outcrops depict the overburden pressure and the tectonic activity both pre- and post-lithification process (Fig. 19). The granular orientation of fragment pore and rock incisions are recorded in thin sections microscopically observed. These patterns are well recorded in almost the entire West Java basin.

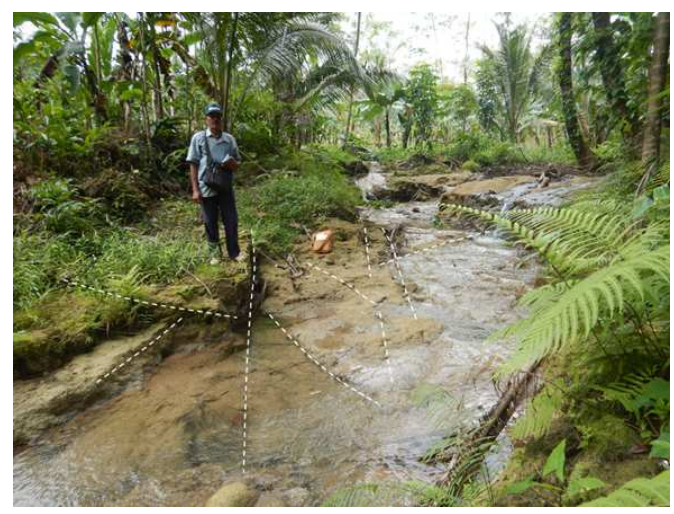

Fig. 19 Fracturing lineaments were imprinted in intraclast bioclastic packstone 


\section{Discussion}

Based on the lithologic and paleontologic characteristics, it is found that there are five types of rocks from Calcarenite Member of Pamutuan Formation deposited in southeast part of West Java Basin. All of them are associated with the presence of reef complex in a platform setting. The position of each unit in this complex can be identified from the composition and physical properties in addition to fossil association.

The first unit is located in the northeast of the reef in the position at the fore slope. Here the Early Middle Miocene rock composed of packstone contain allochton skeletal fragments. Lime clasts embedded in a same-aged matrix are found as the result of debris avalanche of the reef's body. The younger skeletal packstone (Unit 2) spreads in the southern part of the investigated area. Diverse assemblages of foram, algae, coral, and mollusc thrive in a eutropic environment in shallow reefal with bright sunlight and clean waters. This unit is deposited at lee side on the back of reef's body with low sedimentation rate, affected by waves. Finer grained components suggest water release of the mud in the tidal flat forming sag with less contribution of material from outside. The unit 3 consisting of limestones predominated by planktic foram characterizes a deep sedimentary environment in lower slope at the fore reef. The presence of glauconitic minerals augments the indication of changing the environment from shallow marine to the direction of the deeper sea. Interbedded calcareous mudstone and sandstone (Unit 4) are clastic sediments generally deposited in the open sea shelf. The top sequence (Unit 5) is the large unit dominated the reef with grainstone which indicates the dynamic depositional environment in the back reef. The fossil analysis confirms the position in the fore side of the reef where the energy of water in the depositional environment seems to be rather dynamics.

The description of the physical characteristics combined with fossil analysis brings the conclusion of the reef configuration during the formation in the Middle Miocene Time of Tf1(eq. N.10) to Tf2(eq. N.13) (Table 1). The status of calcarenite limestone member in Pamutuan Formation becomes very clear as the reef's body within the tuffaceous marl and sandy marl of shallow to the neritic environment. The evidence might lead to the conclusion that the land area during Middle Miocene was the triangle bounded in the West by Cimandiri Fault while in the East by Citanduy Fault. The investigated area was located in the shallow open sea with the beach more or less in the NNW-SSE direction as indicated by the configuration of the reef.

According to studies of modern carbonate, climate and tectonic activities are known as two overriding controls on the carbonate sedimentation, although there are many other factors which determine the nature of carbonate formation. These factors together control another important variable namely the sea level. The dynamics of the sea-level are shown by the evidence of the characteristics of the lithologic composition and the contained fossils.

The climatic shifts at mid-Miocene are well recorded due to cooling that appeared to spread over a few million years. It is speculated that in latest Early Miocene time the warmest benthic assemblages were replaced gradually by cooler assemblages until late Middle Miocene.

TABLE I

Index Fossils Of Middle Miocene Aged CARbonate-Rock Units

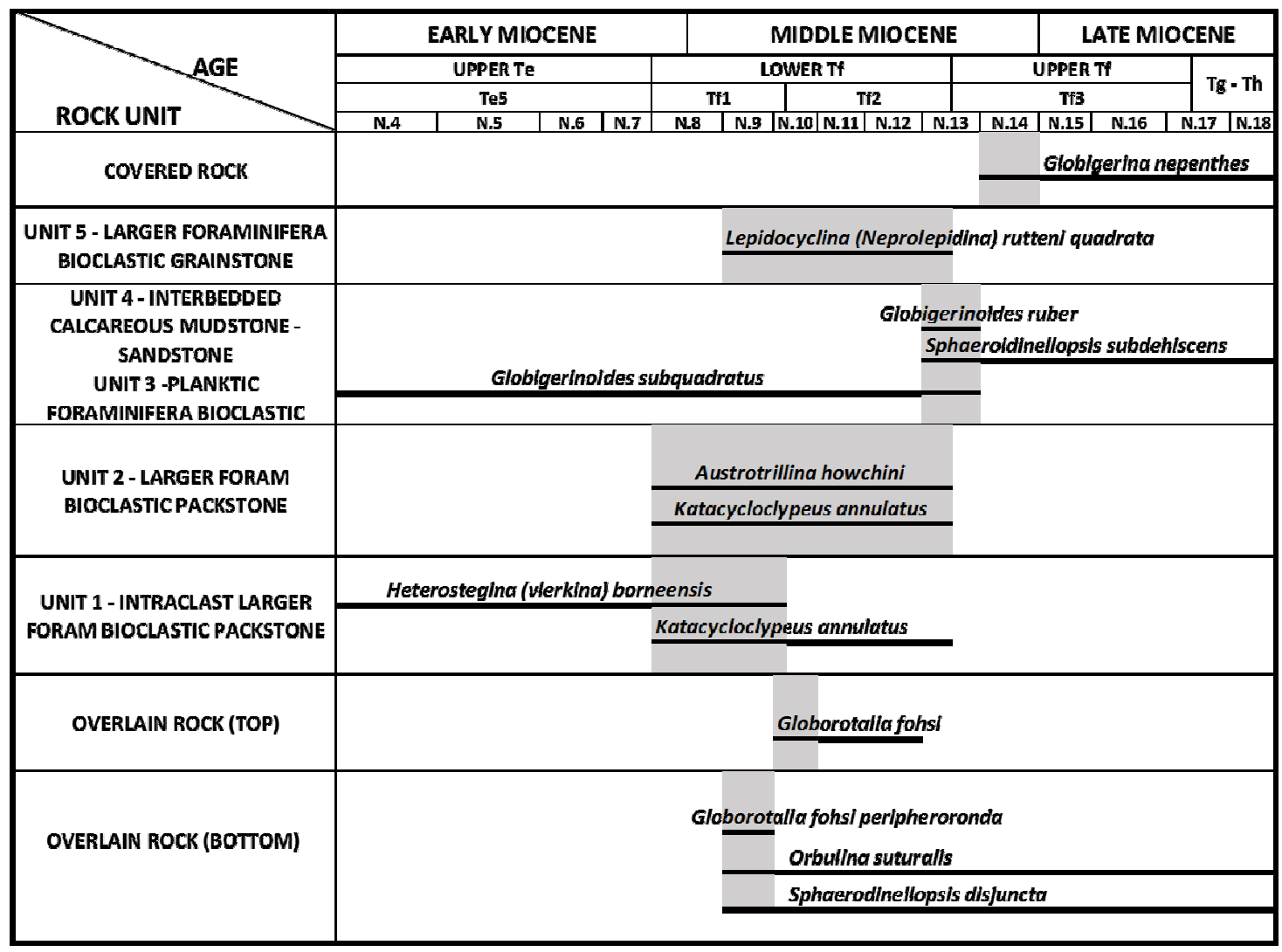


In the beginning, in Early Middle Miocene, the reef complex developed in the shallow marine environment at the offshore of the Island located in the West, presently known as the Western part of Southern Mountain in West Java. The high energy seawater abraded the reef and the basement and finally deposited the fragments in the area of the fore slope. Intraclast larger foram (unit 1) that represents the deposition of this initial phase is interpreted to be originated near from the reef.

Afterward the regressive of the seawater took place producing bioclastic packstone containing larger foram. The lithology represents the backreef environment, where the energy of seawater became less. The sea became deeper as demonstrated by the lithologic changes from larger foram to planktic foram contained in the bioclastic packstone (from Unit 2 to Unit 3). The rock composed of predominant planktic foram indicates the rising sea-level. The formation of planktic packstone marked an initial transgression phase in this area occurring in mid-Middle Miocene.

Sea level transgressive continued producing the formation of Unit 4, the calcareous mudstone interbedded with sandstone. This succession of Unit 3 and 4 was formed during the dynamic transgressive phase in Middle Miocene time that well represented as regional transgressive in Southeast Asia (fewer clastic sources, more drowned land area and prograding highstand, with common carbonate development) [21]. Regional sea level rise period took place during this Middle Miocene that occurred since \pm 13.5 MYBP (eq. N.11) and ended by a decrease of the sea level on \pm 11 MYBP (eq. N.14).

The sea-level regressive dynamics marked by the formation of Unit 5 - grain supported limestone. It was correlated to a global gradual drop in Late Middle Miocene. The development of the Calcarenite Member of the Pamutuan Formation, therefore, commences with the dynamics development of a carbonate platform in the offshore of an Island (Fig. 20).

\section{CONCLUSIONS}

The characteristics of the Calcarenite Member of Pamutuan Formation are verified by a macroscopic and microscopic description of the limestone in the investigated area. Five units are distinguished based on lithological and paleontological characteristics (namely intraclast-larger foram bioclastic packstone, larger foram bioclastic packstone, planktic foram bioclastic packstone, interbedded calcareous mudstone-sandstone, and larger foram bioclactic grainstone). The distribution of the units contributes to the analysis of the dynamics of the development of the Calcarenite Member. Fossil analysis indicates the position of each rock unit in the reef complex at the Early to Late Middle Miocene (Tf1 or N.10 to Tf2 or N.13). Hence the position of the Middle Miocene coastal line might be interpreted showing the NNW-SSE direction. This evidence supports the interpretation of the land area of Southern Mountain and the regional structure. The investigation contributes to clarify the position of Calcarenite Member in Pamutuan Formation as the reef body in the deposition of volcanic clastic. The detailed lithologic description through measured section combined with paleontological and facies analyses reveal the dynamic environment of the Calcarenite Member of Pamutuan Formation.

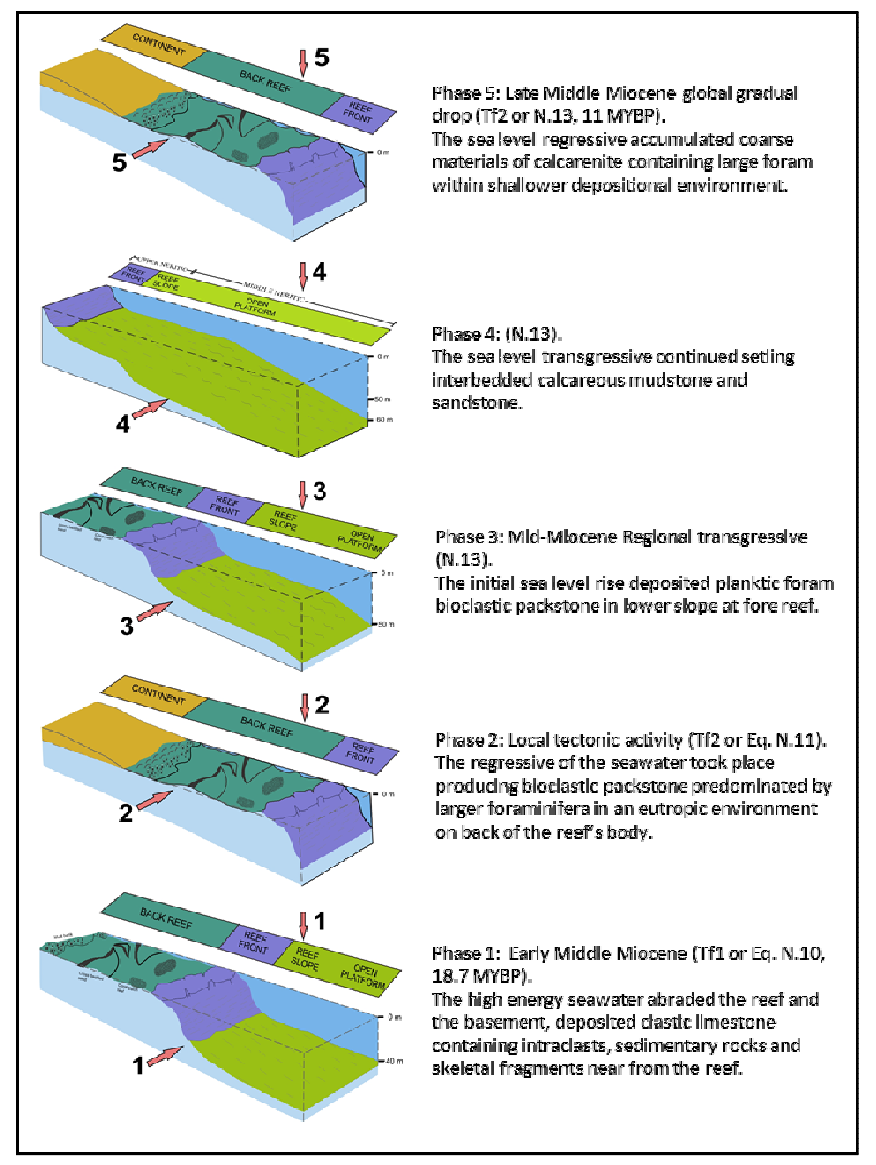

Fig. 20 The dynamics of developing Calcarenite Member of Pamutuan Formation

\section{ACKNOWLEDGMENTS}

This research is funded by Academic Leadership Grants (ALG) no 855UN6.3.1/PL/2017 and 885/UN6.3.1/PL/2017. The authors wish to extends their gratitude to Rector of Universitas Padjadjaranfor the provision of funding and the permission to publish the results of the research. To Professor Nurpilihan Bafdal, who has kindly reviewed the manuscript and offered various suggestions and comments, the authors are deeply indebted. Thanks are due to the Faculty of Geological Engineering that contributed students to assist the author both in the field and in the laboratory.

\section{REFERENCES}

[1] W. Hamilton, "Tectonics of the Indonesian Region," Geol. Soc. Malaysia, vol. Bulletin 6, no. July, pp. 3-10, 1973.

[2] C. S. Hutchison, "Tectonic Evolution of Southeast Asia," Bull. Geol. Soc. Malaysia, vol. 60, no. December, pp. 1-18, 2014.

[3] T. . Simandjuntak and Surono, "Geological Map of Pangandaran Java, Sheet 1308 - 2, scale 1:100.000." Pusat Penelitian dan Pengembangan Geologi, Indonesia, 1992.

[4] I. Syafri, M. Sulastri, O. Sobarin, and P. Khaerani, "Limestone Potential in Cikatomas Region Based on Geological Maping and Its Role Towards Development of Southern Part of West Java , Indonesia Limestone Potential in Cikatomas Region and Its Role Towards Development of Southern Part of West Java , Indonesi," in Proceeding of FIG Working Week 2016. Recovery from Disaster. New Zealand, 2016, no. 1.

[5] A. H. Satyana and M. E. M. Purwaningsih, "Oligo-Miocene carbonates of Java: Tectonic Setting and Effects of Volcanism," in 
Proceedings of Joint Convention Jakarta 2003 . The 32nd IAGI and 28th HAGI Annual Convention and Exhibition, 2003, no. 1, pp. 1-27.

[6] L. Pomar, "Ecological control of sedimentary accommodation: evolution from a carbonate ramp to rimmed shelf, Upper Miocene, Balearic Islands," Palaeogeogr. Palaeoclimatol. Palaeoecol., vol. 175, no. 1, pp. 249-272, 2001.

[7] A. C. Tavares, L. Borghi, P. Corbett, J. Nobre-Lopes, and R. Câmara, "Facies and depositional environments for the coquinas of the Morro do Chaves Formation, Sergipe-Alagoas Basin, defined by taphonomic and compositional criteria," Brazilian J. Geol., vol. 45, no. 3, pp. 415-429, 2015.

[8] B. H. Emraninasab, M. H. Adabi, M. Majidifard, and N. K. Ghadimvand, "Facies Interpretation, Depositional Environment and Sequence Stratigraphy of the Sartakht Formation in the Bakhshi Section, Located in Kalmard Block, East-Central Iran," Open J. Geol., vol. 6, pp. 314-329, 2016.

[9] A. Hashmie, A. Rostamnejad, F. Nikbakht, M. Ghorbanie, P. Rezaie, and H. Gholamalian, "Depositional environments and sequence stratigraphy of the Bahram Formation (middle-late Devonian) in north of Kerman, south-central Iran," Geosci. Front., vol. 7, no. 5, pp. 821-834, 2016.

[10] Z. Khattak, M. A. Khan, Z. Rahman, M. Ishfaque, and M. Yasin, "Microfacies and Diagenetic Analysis of Lockhart Limestone, Shah Alla Ditta Area Islamabad, Pakistan," Pakistan J. Geol., vol. 1, no. 1, pp. 24-26, 2017.

[11] M. Schlaich and T. Aigner, "Facies and integrated sequence stratigraphy of an Epeiric Carbonate Ramp Succession: Dhruma Formation, Sultanate of Oman," Depos. Rec., vol. 3, no. 1, pp. 92132, 2017.

[12] M. H. Adabi, U. Kakemem, and A. Sadeghi, "Sedimentary facies, depositional environment, and sequence stratigraphy of OligoceneMiocene shallow water carbonate from the Rig Mountain, Zagros basin (SW Iran)," Carbonates and Evaporites, vol. 31, no. 1, pp. 69$85,2016$.

[13] M. Omidvar, A. Safari, H. Vaziri-Moghaddam, and H. Ghalavand, "Facies analysis and paleoenvironmental reconstruction of upper cretaceous sequences in the eastern Para-Tethys basin, NW Iran," Geol. Acta, vol. 14, no. 4, pp. 363-384, 2016.

[14] M. A. Jambak, I. Syafri, V. Isnaniawardhani, B. Benyamin, and H. Rodriguez, "Facies and Diagenetic Level of the Upper Cibulakan and Parigi Formation, in Randegan and Palimanan Area," Indones. J.
Geosci., vol. 2, no. 3, pp. 157-166, 2015.

[15] V. Isnaniawardhani, R. Rinawan, and B. Prianggoro, "The Fossing Assemblage Features of Limestone and Clastic Sedimentary Rock in Lulut Area, Cileungsi District, Bogor, West Java," Bull. Sci. Contrib. vol. 10, no. 2, pp. 96-107, 2012.

[16] F. A. Pomoni and V. Karakitsios, "Sedimentary facies analysis of a high-frequency, small-scale, peritidal carbonate sequence in the Lower Jurassic of the Tripolis carbonate unit (central western Crete, Greece): Long-lasting emergence and fossil laminar dolocretes horizons," J. Palaeogeogr., vol. 5, no. 3, pp. 241-257, 2016.

[17] M. K. BouDagher-Fadel, G. D. Price, and E. A. M. Koutsoukos, "Foraminiferal biostratigraphy and paleoenvironments of the Oligocene-Miocene carbonate succession in Campos Basin, southeastern Brazil," Stratigraphy, vol. 7, no. 4, pp. 283-299, 2010.

[18] J. Spanicek, V. Cosovic, E. Mrinjek, and I. Vlahovic, "Early Eocene evolution of carbonate depositional environments recorded in the Čikola Canyon (North Dalmatian Foreland Basin, Croatia)," Geol. Croat., vol. 70, no. 1, pp. 11-25, 2017.

[19] M. K. Boudagher-Fadel and S. W. Lokier, "Significant Miocene larger foraminifera from South Central Java," Rev. Paleobiol., vol. Geneve 24, no. 1, pp. 291-309, 2005.

[20] M. K. BouDagher-Fadel and M. Wilson, "A revision of some larger foraminifera of the Miocene of Southeast Kalimantan.pdf," Micropaleontology, vol. 46, no. 2, pp. 153-165, 2000.

[21] A. Chalabi, B. Pierson, and J. A. Talib, "Remote Sensing Analysis of Recent Carbonate Platforms, East of Sabah: Potential Analogues for Miocene Carbonate Platforms of the South China Sea," Indones. J. Geol., vol. 7, no. 3, pp. 123-135, 2012.

[22] J. T. van Gorsel, "Biostratigraphy In Indonesia: Metods, Pitfalls and New Direction," in Proc. Indonesian Petroleum Association, 17th Annual Convention, 1988, no. October.

[23] V. Isnaniawardani and Nurdrajat, "Miocene Planktonic Foraminiferal Biodatum of the Jatiluhur Sections in Northwest Java Basin," in Procceding of the 2nd International Conference and 1st Joint Conference Faculty of Geology Universitas Padjadjaran and Faculty of Science and Natural Resources University Malaysia Sabah, 2015. p. 111.

[24] E. F. Sharaf, M. K. Boudagher-fadel, J. A. T. Simo, and A. R. Carroll, "Biostratigraphy and strontium isotope dating of Oligocene-Miocene strata , East Java , Indonesia," Stratigraphy, vol. 2, no. 3, pp. 1-19, 2005 . 